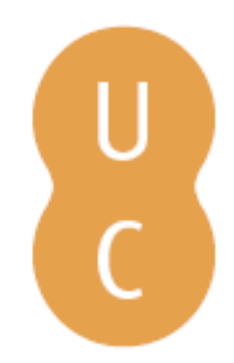

\title{
pompalina
}

\section{Aerodynamic study of the airflow around a scale triangular prismatic hill for Low Reynolds Number}

\author{
Autor(es): $\quad$ Conceição, Eusébio Z. E.; Lúcio, Mํㅡㄹ Manuela J. R.; Viegas, Domingos
}

Publicado por: Imprensa da Universidade de Coimbra

URL persistente:

URI:http://hdl.handle.net/10316.2/44687

DOI: $\quad$ DOI:https://doi.org/10.14195/978-989-26-16-506_170

Accessed : $\quad$ 26-Apr-2023 10:45:39

A navegação consulta e descarregamento dos títulos inseridos nas Bibliotecas Digitais UC Digitalis, UC Pombalina e UC Impactum, pressupõem a aceitação plena e sem reservas dos Termos e Condições de Uso destas Bibliotecas Digitais, disponíveis em https://digitalis.uc.pt/pt-pt/termos.

Conforme exposto nos referidos Termos e Condições de Uso, o descarregamento de títulos de acesso restrito requer uma licença válida de autorização devendo o utilizador aceder ao(s) documento(s) a partir de um endereço de IP da instituição detentora da supramencionada licença.

Ao utilizador é apenas permitido o descarregamento para uso pessoal, pelo que o emprego do(s) título(s) descarregado(s) para outro fim, designadamente comercial, carece de autorização do respetivo autor ou editor da obra.

Na medida em que todas as obras da UC Digitalis se encontram protegidas pelo Código do Direito de Autor e Direitos Conexos e demais legislação aplicável, toda a cópia, parcial ou total, deste documento, nos casos em que é legalmente admitida, deverá conter ou fazer-se acompanhar por este aviso.

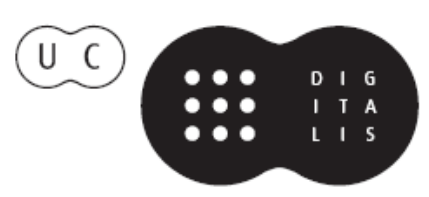




\section{ADVANCES IN}

\section{FOREST FIRE RESEARCH}

\section{8}

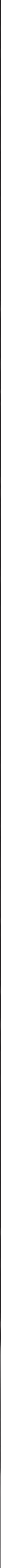


Short contribution - Fire at the Wildland Urban Interface

\title{
Aerodynamic study of the airflow around a scale triangular prismatic hill for Low Reynolds
} Number

\author{
Eusébio Z. E. Conceição ${ }^{1}, \mathrm{M}^{\mathrm{a}}$ Manuela J. R. Lúcio ${ }^{1}$, Domingos X. Viegas ${ }^{2}$, and Maria T. Viegas ${ }^{2}$ \\ ${ }^{1}$ FCT - University of Algarve - Campus de Gambelas - 8005-139 Faro, Portugal \\ ${ }^{2}$ FCT - University of Coimbra - Pinhal de Marrocos - Pólo II - 3030 Coimbra, Portugal
}

\begin{abstract}
In this work is made the aerodynamic study of the airflow around a scale triangular prismatic hill for low Reynolds number. The study is made experimentally and numerically. The numerical simulation is used to complement the experimental results. The study considers a scale triangular prismatic hill with $4 \mathrm{~cm}$ of side and $20 \mathrm{~cm}$ of length. The scale triangular prismatic hill is located inside a channel with a square section, with $20 \mathrm{~cm}$ of side and $100 \mathrm{~cm}$ of length. The experimental study is made in a low air velocity aerodynamic tunnel, with a square experimental section of $20 \times 20$ $\mathrm{cm}^{2}$. In the experimental test, the airflow around a scale triangular prismatic hill is obtained using the smoke visualization, a laser and a film machine. In the image acquisition a rate of 25 images per second is used. In the numerical simulation the Computational Fluid Dynamics is used. The Computational Fluid Dynamics numerical model considers the two-dimensional turbulent airflows under steady-state and non-isothermal conditions. In the study the air velocity is $0.15 \mathrm{~m} / \mathrm{s}$. The air velocity is controlled, in the experimental tunnel, using a Babuc-A and confirmed in the final using a graphic methodology. In the paper the airflow around a scale triangular prismatic hill is analysed. The vortexes dimensions in steady state conditions are numerically calculated, while the vortexes formation in transient conditions are experimentally analysed.
\end{abstract}

Keywords: Numerical Simulation, Experimental Tests, Aerodynamic Study, Airflow Around a Scale Triangular Prismatic Hill.

\section{Introduction}

The airflow around triangular prim hills was studied in the last years. The idea of this study is to evaluate the airflow amount and downstream of the triangular prismatic hill. This study is important because the airflow verified in the downstream area, in a forest fire situation, can return the fire to the triangular prismatic area.

The aerodynamic tunnel is used and applied in studies of airflow in controlled conditions. Several studies were developed in the aerodynamic of the forest fire and of the terrain topology. However, in this study the aerodynamic tunnel is used to evaluate the airflow around triangular prismatic hills.

The Computational Fluid Dynamics numerical model, developed in the last years by the authors, can be seen in detail in Conceição et al. (2008) and Conceição et al. (2016), was validated and applied in experimental chamber with controlled thermal conditions.

\section{Mathematical Model}

The Computational Fluid Dynamics numerical model, used in this work, considers the twodimensional turbulent airflows under steady-state and non-isothermal conditions. The numerical model, developed by the authors, can be seen in detail in Conceição et al. (2008) and Conceição et al. (2016). The numerical model solves the partial differential equations (using the finite volume method), namely, the mass continuity equation, moment equations (two-dimensional air velocity), energy 
equation, turbulence kinetic energy equation and turbulence energy dissipation rate equation (using the RNG turbulence model). This numerical model is used to evaluate the airflow around a hill (twodimensional components of air velocity, air temperature, air pressure, turbulent kinetic energy and turbulent energy dissipation rate).

\section{Experimental test}

The experimental study is made in a low air velocity aerodynamic tunnel with recirculation. The low air velocity aerodynamic tunnel has a height of $3 \mathrm{~m}$ and a length of $6 \mathrm{~m}$. The test section, with a transparent perspex square experimental section of $20 \times 20 \mathrm{~cm} 2$, has a length of $1 \mathrm{~m}$ (see figure 1). In the experimental test, the airflow around a scale triangular prismatic hill is obtained using the smoke visualization, a laser and a film machine. In the image acquisition, a rate of 25 images per second is used.

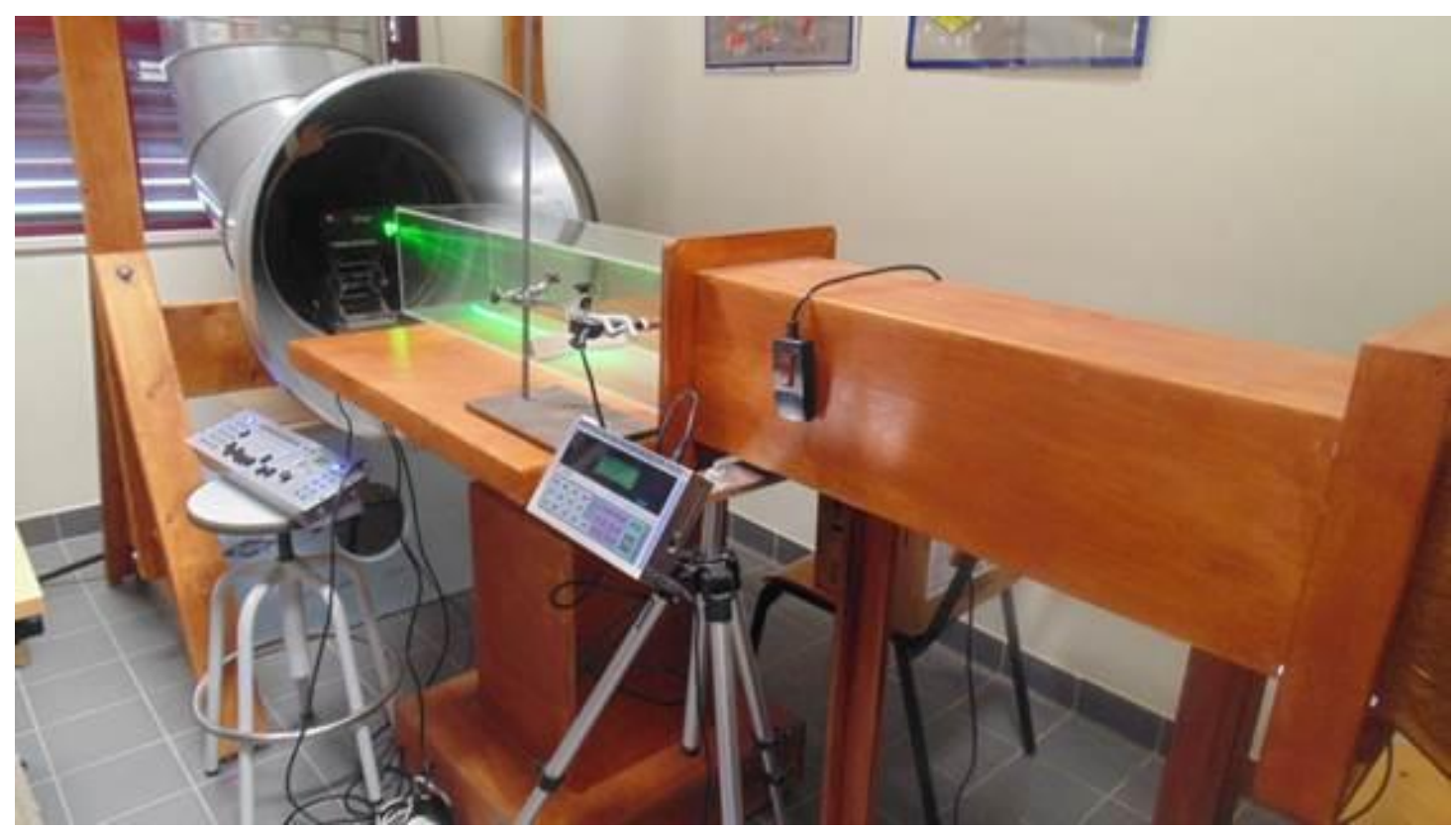

Figure 1 - Scheme of the low air velocity aerodynamic tunnel, test section and laser used in the experimental tests.

The study considers a scale triangular prismatic hill with $4 \mathrm{~cm}$ of side and $20 \mathrm{~cm}$ of length. The scale triangular prismatic hill is located inside a channel with a square section, with $20 \mathrm{~cm}$ of side and $100 \mathrm{~cm}$ of length (see figure 2).

In the study the air velocity is $0.15 \mathrm{~m} / \mathrm{s}$. During the experimental study the air velocity is controlled, using a Babuc-A. In the final, using a graphic methodology, the air velocity is confirmed.

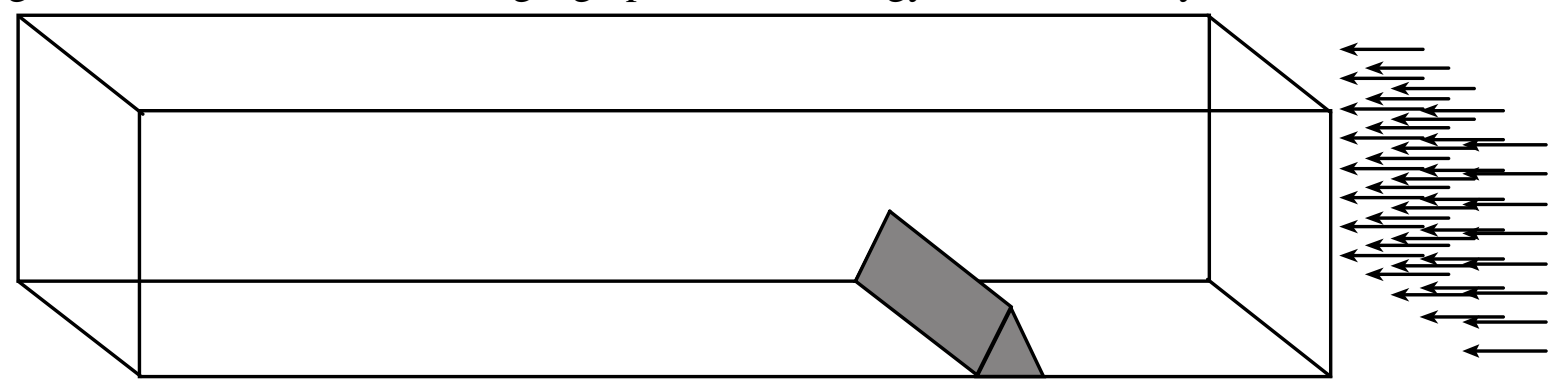

Figure 2 - Scheme of the test section equipped with a triangular prismatic hill. 


\section{Numerical Methodology}

The numerical study is made using a Computational Fluid Dynamics numerical model. The numerical simulation, using a 2D simulation, can be seen in figure 3 . The study considers a triangle with $4 \mathrm{~cm}$ of side. The simulation domain are $20 \mathrm{~cm}$ of height and $100 \mathrm{~cm}$ of length.

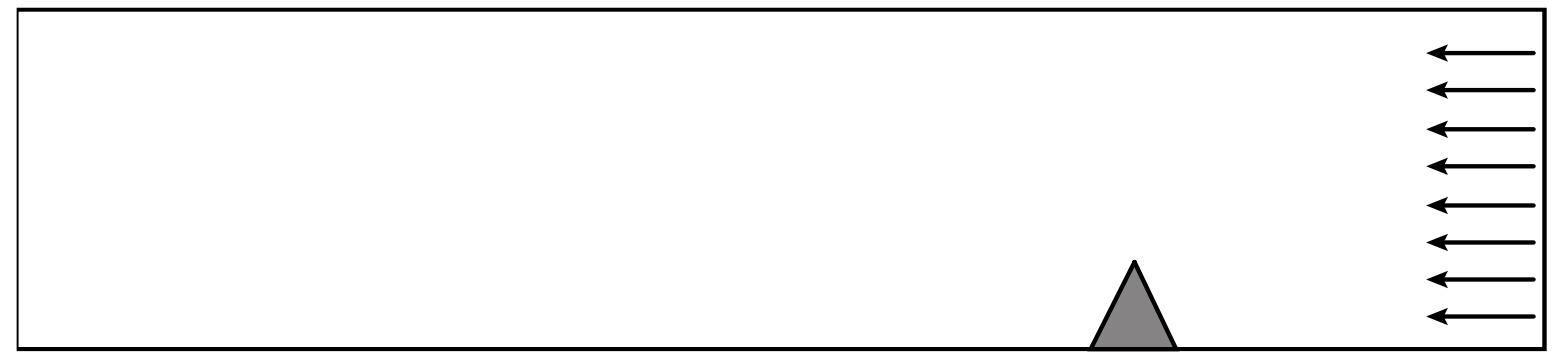

Figure 3 - Numerical simulation scheme of the section equipped with a triangular prismatic hill.

\section{Results and Discussion}

In this section the numerical and the experimental results are presented. The aerodynamic study of the airflow around a scale triangular prismatic hill for low Reynolds number is developed.

\section{Experimental test}

In the experimental tests the vortexes formation in transient conditions are presented in figure 4 . In these figures three sequences of 21 images, obtained in $2.52 \mathrm{~s}$, are presented.

In figure 5 is presented the identification of the main parts of the vortex in the downstream triangular prismatic hill. This identification is obtained in accordance to the results obtained in figure 4 .

In accordance to the obtained experimental results, the main vortex can be divided in four parts, namely, the development, the upper transport, the lower return and the recirculation.

\section{Development:}

The vortex development is made in the up downstream area of the triangular prismatic hill, in the upward direction. The development is periodic. The periodicity is around $1.9 \mathrm{~s}$.

\section{Upper Transport:}

The vortex transport is made in the upper main vortex area, in airflow direction. 

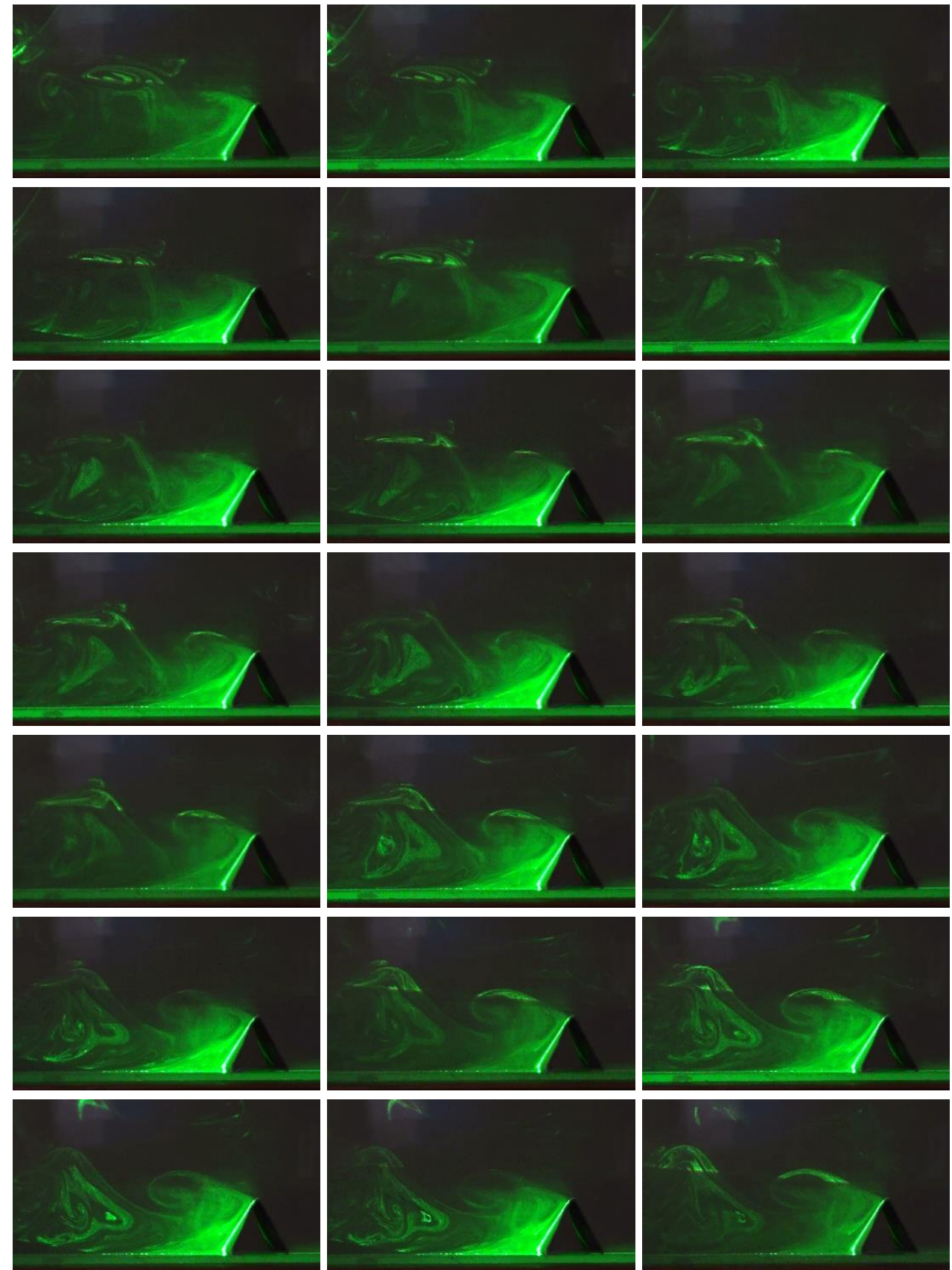

Figure 4 - Experimental tests of the airflow around a scale triangular prismatic hill. Figure integrating a sequence of 21 images.

\section{Lower Return:}

The lower return, made in the lower downstream main vortex area, is responsible to the power supply of the vortex developed (see figure 5), with the direction opposite to the airflow. 

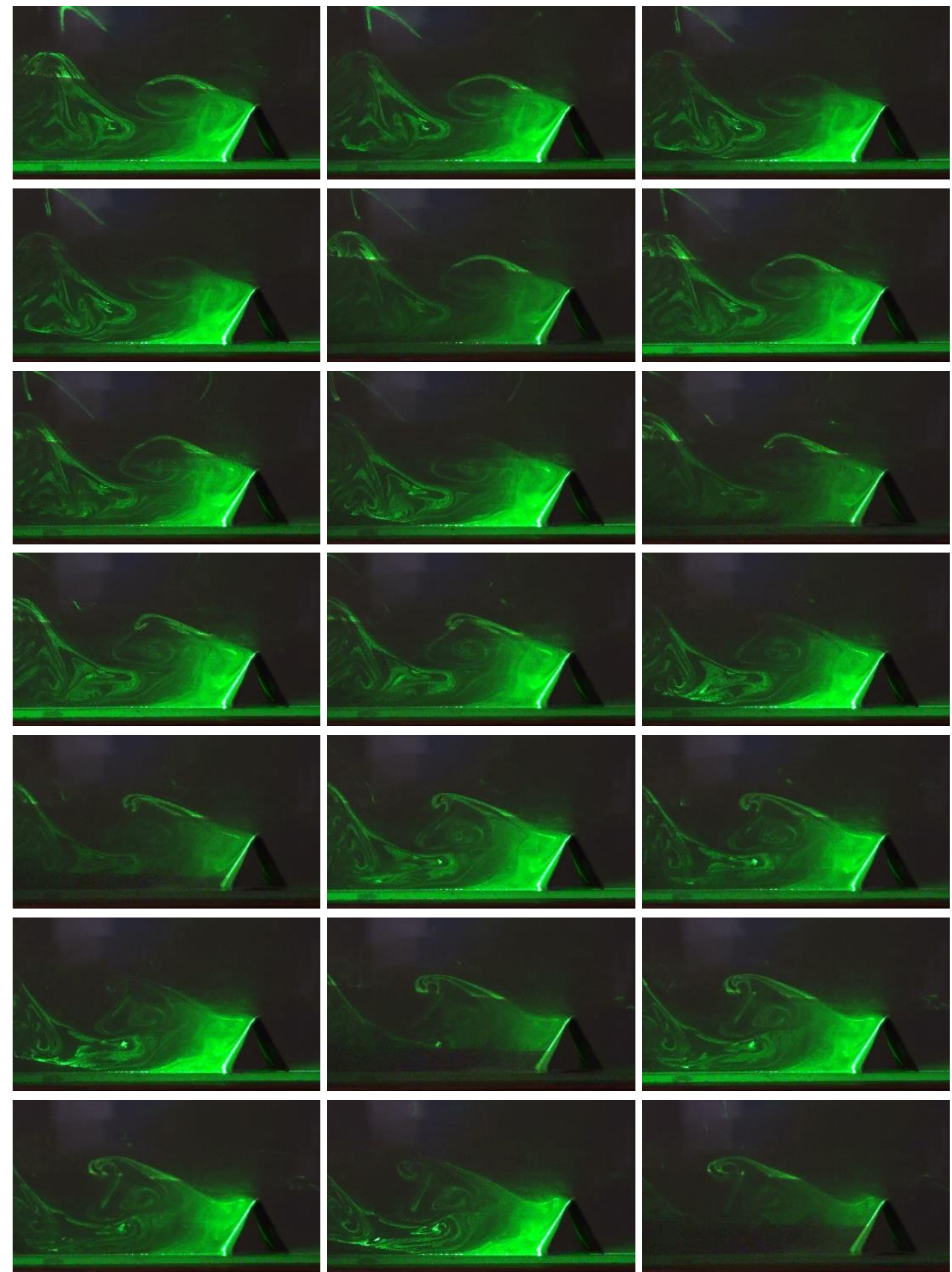

Figure 4 - Experimental tests of the airflow around a scale triangular prismatic hill. Figure integrating a sequence of 21 images (continuation).

\section{Recirculation:}

The circulation is verified in the main vortex centre. The direction of recirculation is made in the upper area in the direction of the airflow and in the lower area in the opposite direction to the airflow. 

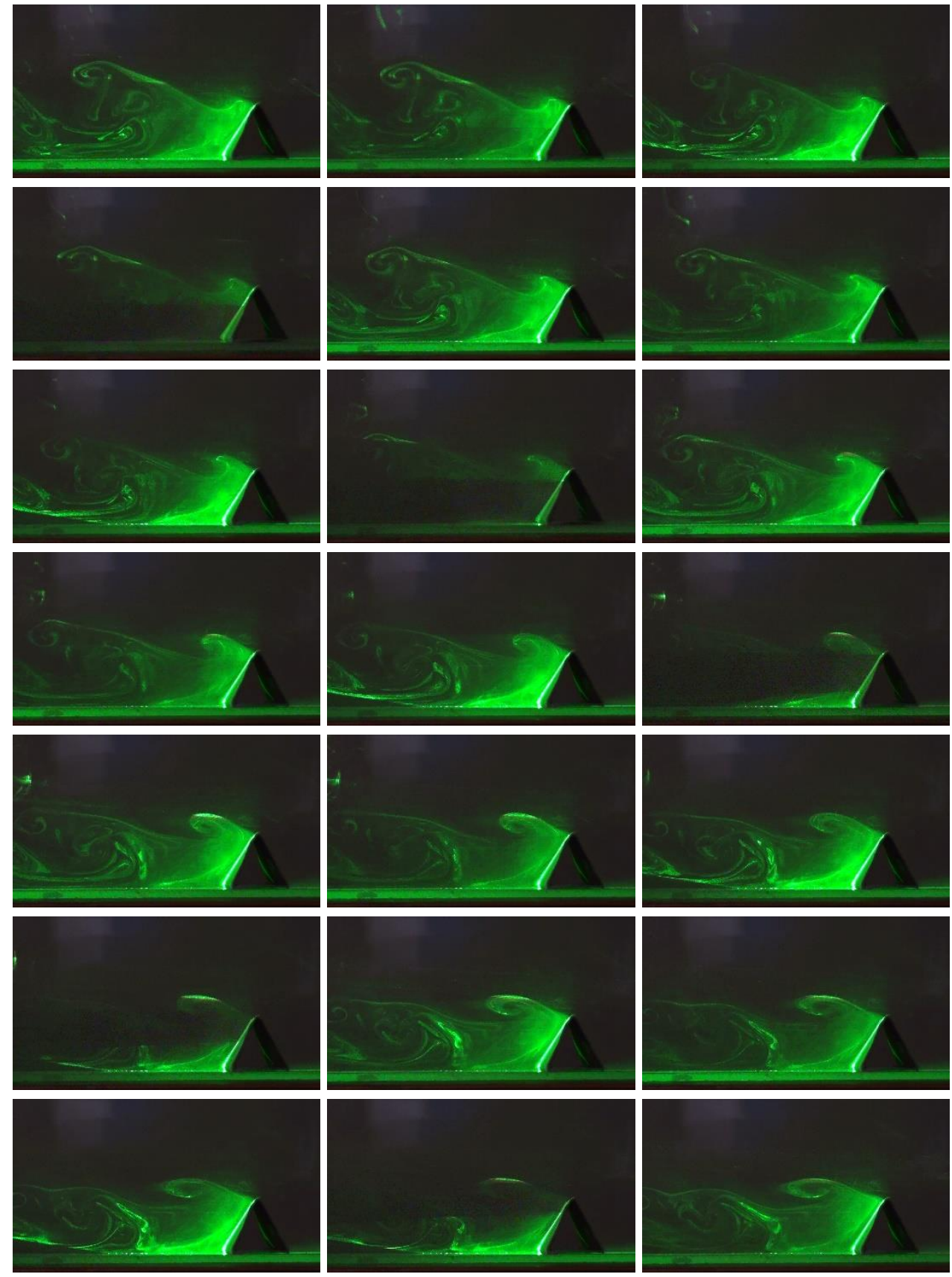

Figure 4 - Experimental tests of the airflow around a scale triangular prismatic hill. Figure integrating a sequence of 21 images (continuation).

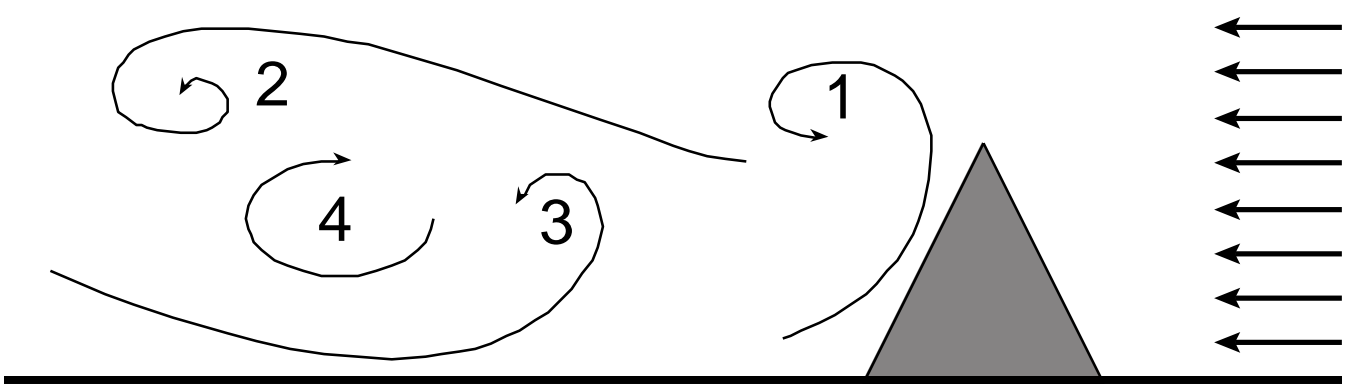

Figure 5 - Identification of the main components of the vortex in the downstream triangular prismatic hill. 


\section{Numerical simulation}

The idea of the numerical simulation, using the RNG k-epson turbulence model, is to obtain a main idea of the airflow topology around the triangular prismatic hill, namely in amount and mainly in the downstream area.

The numerical simulation results, used to obtain the vortexes dimension in steady state conditions, is presented in figure 6 . The influence of the vortexes length is function to the inlet air velocity and the triangular prismatic hill dimensions.

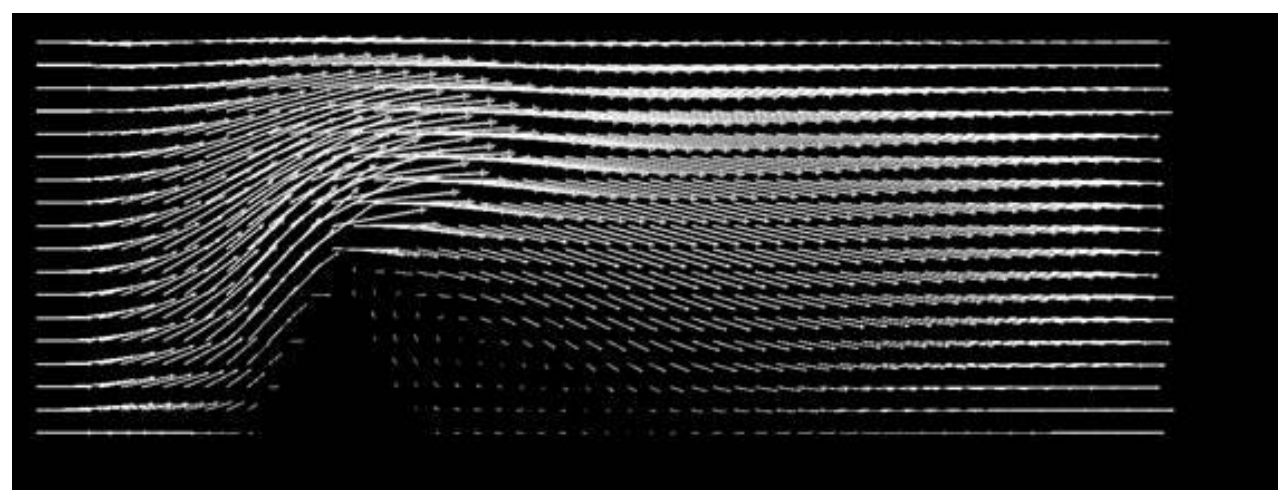

Figure 6 - Numerical tests of the airflow around a scale triangular prismatic hill.

The recirculation area in amount to the triangular prismatic hill, in accordance with the obtained results, verified in the lower area, is small. This fact is associated with the prismatic hill confutation and inclination.

In accordance with the obtained results, in the downstream area, the vortex dimension present a height equal to the triangular prismatic hill side. The vortex length is approximately 1.5 of the triangular prismatic hill side.

\section{Conclusions}

In this work is made the aerodynamic study of the airflow around a scale triangular prismatic hill for low Reynolds number. The study is made experimentally and numerically. The experimental study is made in a low air velocity aerodynamic tunnel, while the numerical study is developed using a Computational Fluid Dynamics numerical model.

The study considers a scale triangular prismatic hill with $4 \mathrm{~cm}$ of side and $20 \mathrm{~cm}$ of length. The scale triangular prismatic hill is located inside a channel with a square section with $20 \mathrm{~cm}$ of side and with $100 \mathrm{~cm}$ of length.

In the experimental test was analysed in detail vortex, in the downstream area. In acordance with the experimental obtained results, the vortex has a frequency of $0.52 \mathrm{~Hz}$. The vortex has a development in the upper triangular prismatic hill area, has a transport in the upper area in the airflow direction, has a return down downstream main vortex area with the direction opposite to the airflow and has a recirculation in the in the main vortex centre.

In the numerical tests was verified a first vortex, located amount the triangular prismatic hill, with very small dimension, and a second vortex, located downstream the triangular prismatic hill, with a height equal to the prismatic hill side and with a length approximate to 1.5 of the prismatic hill side.

In this work the two dimensional airflow study is made. In future works is suggest the three dimensional evaluation of the airflow downstream of the triangular prismatic hill. 


\section{References}

Conceição, E. Z. E., Santiago, C. I. M. and Awbi, H. B. 2016. Numerical Study of Different Ceiling Mounted Localized Air Distribution Systems For a Virtual Classroom, Indoor and Building Environment, July 19.

Conceição, E. Z. E., Vicente, V. D. S. R. and Lúcio. Ma M. J. R. 2008. Airflow inside school buildings office compartments with moderate environment. International Journal on Heating Air Conditioning and Refrigerating Research, ASHRAE, Vol. 14, N. 2, March 2008, pp. 195-207. 